\title{
Community ecology of the metazoan parasites of namorado sandperches, Pseudopercis numida Miranda-Ribeiro, 1903 and P. semifasciata Cuvier, 1829 (Perciformes: Pinguipedidae), from the coastal zone of the State of Rio de Janeiro, Brazil
}

\author{
Luque, JL. ${ }^{\mathrm{a} *}$, Felizardo, NN. ${ }^{\mathrm{b}}$ and Tavares LER. ${ }^{\mathrm{a}}$ \\ a Departamento de Parasitologia Animal, Universidade Federal Rural do Rio de Janeiro - UFRRJ, \\ CP 74508, CEP 23851-970, Seropédica, RJ, Brazil

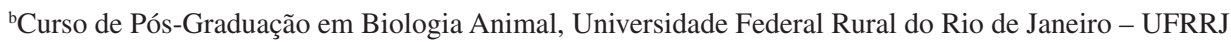 \\ *e-mail: jlluque@ufrrj.br \\ Received May 25, 2006 - Accepted July 10, 2006 - Distributed May 31, 2008
}

\begin{abstract}
One hundred and twenty-eight specimens of namorado sandperches, 62 P. numida and 66 P. semifasciata, collected between October 2002 and June 2003 off the Cabo Frio, Rio de Janeiro, Brazil (Lat $23^{\circ} \mathrm{S}$ and Long 42 ${ }^{\circ} \mathrm{W}$ ), were examined to study their metazoan parasites. Parasite communities of these fish were composed basically of endoparasites, mainly digenean and cestodes species, with low prevalence and abundance but having high parasite species richness values (at the component community level). Among these values, that found for $P$. numida is the highest so far recorded for marine fishes from the Neotropical Region. Thirty-nine species of metazoan parasites were collected: 36 from $P$. numida and 28 from $P$. semifasciata. Twenty-five parasite species were common to both species of namorado sandperches. Pseudopercis numida and P. semifasciata are new host records for all parasite species collected, with the exception of Microcotyle pseudopercis. Choanodera sp., Leurodera decora, Neolebouria georgenascimentoi, and Proctoeces sp. which were recorded for the first time in the South American Atlantic Ocean. Gnathia sp. from $P$. numida and Scolex pleuronectis from P. semifasciata were the species having the greatest dominance frequency. Parasite abundance in $P$. numida and $P$. semifasciata were positively correlated with the host total length. Only in $P$. numida was parasite species richness correlated positively with the host total length. No significant differences between endoparasite infracommunities of $P$. numida and $P$. semifasciata were detected. The ectoparasites of $P$. numida had higher values for parasite abundance, parasite richness, Brillouin index, evenness index, and Berger-Parker index than those of the ectoparasites of $P$. semifasciata. Comparisons among all ecto- and endoparasites showed the ectoparasites of $P$. numida as the most heterogeneous group. Low similarity values were observed among the three types of parasite infracommunities of the two hosts.
\end{abstract}

Keywords: parasite ecology, community structure, marine fish, Pinguipedidae, Pseudopercis, Brazil.

\section{Ecologia da comunidade de metazoários parasitos dos namorados, Pseudopercis numida e P. semifasciata (Perciformes: Pinguipedidae), do litoral do estado do Rio de Janeiro, Brasil}

\footnotetext{
Resumo

Cento e vinte e oito espécimes de namorados, 62 P. numida e 66 P. semifasciata, foram coletados entre Outubro de 2002 e Junho de 2003, provenientes de Cabo Frio, litoral do Estado do Rio de Janeiro, Brasil (Lat $23^{\circ} \mathrm{S} \mathrm{e} \mathrm{Long} 42^{\circ} \mathrm{W}$ ), sendo necropsiados para estudo de seus metazoários parasitos. As comunidades parasitárias dos namorados foram compostas por espécies com baixa prevalência e abundância, mas caracterizadas por altos valores de riqueza de espécies (no nível de comunidade componente) e incluem basicamente endoparasitos, principalmente espécies de digenéticos e cestóides. A riqueza parasitária em $P$. numida foi registrada como a mais alta em peixes marinhos da região Neotropical. Trinta e nove espécies de metazoários parasitas foram coletadas: 36 em $P$. numida e 28 em $P$. semifasciata. Pseudopercis numida e $P$. semifasciata são novos registros de hospedeiros para todas as espécies coletadas com exceção de Microcotyle pseudopercis. As espécies Choanodera sp., Leurodera decora, Neolebouria georgenascimentoi e Proctoeces sp. foram registradas pela primeira vez no Oceano Atlântico Sul. Gnathia sp. em P. numida, e Scolex pleuronectis em $P$. semifasciata foram as espécies com maior freqüência de dominância. A abundância parasitária em $P$. numida e $P$. semifasciata foi correlacionada com o comprimento total dos hospedeiros. Apenas em $P$. numida a riqueza de espécies de parasitas estava correlacionada positivamente com o comprimento total do hospedeiro. As infracomunidades de ectoparasitos em $P$. numida tiveram valores mais altos na abundância parasitária, riqueza parasi-
} 
tária, índice de Brillouin, índice de uniformidade e Berger-Parker do que os ectoparasitos de P. semifasciata. Nenhuma diferença significativa entre as infracomunidades de endoparasitas foi detectada. Comparações entre ectoparasitos e endoparasitos amostrados indicaram os ectoparasitos de $P$. numida como o grupo mais heterogêneo. Baixos valores de similaridade foram observados entre os três tipos de infracomunidades de parasitas dos dois hospedeiros.

Palavras-chave: ecologia parasitária, estrutura comunitária, peixes marinhos, Pinguipedidae, Pseudopercis, Brasil

\section{Introduction}

In the past two decades, several studies have focused on characteristics of the parasite communities of Neotropical marine fishes. Some of them included descriptive characteristics of the infracommunities (Luque, 2004) and, recently, other studies have appeared on biodiversity and component communities (Luque and Poulin, 2004; Luque et al., 2004) in the Brazilian marine fishes. Nevertheless, these studies are apparently insufficient in view of the high fish species biodiversity of the region and possible participation of these species in complex marine food webs. These webs are strongly affected by water currents, upwelling, and resurgence systems, which could be large-scale influences on the structure and composition of the parasite communities (Santos and Carbonel, 2000; Luque et al., 2004).

The namorado sandperches, Pseudopercis numida Miranda-Ribeiro, 1903 and P. semifasciata (Cuvier, 1829) are demersal non-migratory fishes found on rocky and sandy bottoms in coastal waters. These species are considered euryphagous predators, feeding mainly on benthic fishes and crustaceans (Menezes and Figueiredo, 1985; Elías and Rajoy, 1992; Froese and Pouly, 2005). The known geographical distribution of $P$. numida is restricted to southern Brazil from Rio de Janeiro to the State of Santa Catarina, while P. semifasciata is distributed from the State of São Paulo (Brazil) to the Gulf of San Jorge (Argentina) (Menezes and Figueiredo, 1985). Nevertheless, some records mention the presence of P. semifasciata in the State of Rio de Janeiro (Froese and Pauly, 2007).

Although these fishes are important economically, records of parasites of namorado sandperches are few. However, Amato and Cezar (1994) described the monogenean Microcotyle pseudopercis parasitic on P. numida and P. semifasciata from Rio de Janeiro, Brazil, and González and Tanzola (2000) recorded the copepod Sarcotaces verrucosus parasitic on P. semifasciata from the Gulf of San Matías, Argentina. Some studies on distribution, feeding habits, and reproductive aspects of namorado sandperches have been conducted by Elías and Rajoy (1992), Paiva and Andrade-Tubino (1998) and Venerus et al. (2005).

Position in the marine food web, lack of migratory habits, and the restricted known geographical distribution of namorado sandperches might influence the biodiversity and structure of their parasite communities. In this report, we analyze and compare the composition and the structure of metazoan parasite communities, at the component and infracommunity levels, of $P$. numida and
P. semifasciata from the coastal zone of the State of Rio de Janeiro, Brazil.

\section{Material and Methods}

A total of 128 specimens of namorado sandperches, 62 P. numida and 66 P. semifasciata were examined for metazoan parasites. Fish were caught by long line at irregular intervals between October 2002 and June 2003 in Cabo Frio, Rio de Janeiro State, Brazil (Lat $23^{\circ} \mathrm{S}$, and Long $42^{\circ} \mathrm{W}$ ). They were identified according to Menezes and Figueiredo (1985). Sandperches were kept fresh or else deep frozen in plastic bags at $-18{ }^{\circ} \mathrm{C}$ until examination. After defrosting each fish was measured. Specimens of $P$. numida measured $36-83$ (mean $=47.7 \pm 7.7 \mathrm{~cm}$ ) and specimens of $P$. semifasciata $26-64($ mean $=38.7 \pm 7 \mathrm{~cm})$ in total length. Parasites were collected from the body surface, gills, branchial and body cavities, and viscera after examination under a stereoscopic microscope. Washings from gills and gut lumen were strained using a sieve (154 $\mu \mathrm{m}$ mesh size) to retain even the smallest parasites.

Following Bush et al. (1997), prevalence, intensity, and abundance were calculated for parasites of both fish species. For those parasite species with higher than $10 \%$ prevalence and common to two fish hosts (component species sensu Bush et al. (1990)), chi-squared analyses were used to test significant differences of parasite prevalence in the two species of sandperches. In addition, Student $t$-test on $\log (\mathrm{x}+1)$ transformed data was used to analyze the effects of the fish host on the abundance of each parasite species (Zar, 1996). The variance-tomean ratio of parasite abundance (index of dispersion) and the discrepancy index, computed using the program Quantitative Parasitology 3.0 (Rósza et al., 2000), were used to detect distribution patterns of the infrapopulations (Poulin, 1993).

The following community descriptors were calculated at the infracommunity level: number of parasite individuals (total abundance), species richness, Brillouin's diversity index (log 10 based), evenness associated with Brillouin's diversity index, Berger-Parker dominance index, and percentage of infracommunities in which either parasite species was dominant (dominance frequency). In addition, two measures of similarity, the Jaccard qualitative and the Sørensen quantitative indices, were calculated among infracommunities within and between host fish species (Magurran, 1988). These descriptors were used for all parasites combined, ectoparasites (monogeneans, hirudineans, and isopods), and endoparasites (trematodes, cestodes, acanthocephalans, and nematodes). The effects of host length on community descriptors were 
evaluated using Student's $t$-test on $\log (x+1)$ transformed data (abundance) and the Pearson correlation coefficient on angular-transformed data (prevalence) (Zar, 1996). Statistical significance level was established at $\mathrm{p}<0.05$.

For each fish species, the average taxonomic distinctness $\left(\Delta^{+}\right)$and variance in taxonomic distinctness $\left(\Lambda^{+}\right)$of the parasite component community were computed, following the procedures and taxonomies used by Luque et al. (2004).

\section{Results}

\subsection{Component communities}

Thirty-nine species of metazoan parasites were collected: 36 from $P$. numida and 28 from $P$. semifasciata (Table 1). Pseudopercis numida and P. semifasciata are new host records for all species collected with the exception of Microcotyle pseudopercis. Twenty-five parasite species were common to both species of namorado sandperches. Choanodera sp., Leurodera decora, Neolebouria georgenascimentoi, and Proctoeces sp. were recorded for the first time in the South Atlantic Ocean (Table 1). Pseudopercis numida showed higher parasite species richness than that of $P$. semifasciata, and the endoparasite group had a higher species richness than that of ectoparasites in the two hosts. Digeneans showed the highest species richness, with 14 species in $P$. numida and 13 in $P$. semifasciata, but represented only $5.4 \%$ and $14.9 \%$ of the total parasite specimens collected, respectively, while isopods $(67.2 \%)$ and cestodes $(41.2 \%)$ made up the majority of specimens collected in $P$. numida and $P$. semifasciata, respectively.

Gnathia sp. in P. numida, and Scolex pleuronectis in $P$. semifasciata were the species with the highest dominance frequency. All parasites had a typically aggregated distribution pattern and all species showed discrepancy index values higher than 0.6 (Table 2). Values of the two indices for parasite species common to the two host species showed no significant differences when tested with paired Student test ( $t=1.214, \mathrm{p}=0.253$ for variance-tomean ratio; $t=-0.365, \mathrm{p}=0.722$ for discrepancy index). In P. numida, only two species showed a positive correlation between the hosts' total length and their prevalences, and five species showed positive correlation between the hosts' total length and abundance. In P. semifasciata, seven species showed positive correlation between the hosts' total length and abundance (Table 3). In comparing prevalence and abundance of the parasite species common to $P$. numida and $P$. semifasciata differences were detected in the prevalence of four species (didymozoid, L. decora, Cucullanus carioca, and Gnathia sp.), and in the abundance of five species (didymozoid, L. decora, M. pseudopercis, Progrillotia dollfusi, and Gnathia sp.) (Table 4).

Average taxonomic distinctness and variance values were similar for the parasite communities of $P$. numida $\left(\Delta^{+}=88.35, \Lambda^{+}=286.73\right)$ and $P$. semifasciata $\left(\Delta^{+}=86.52\right.$, $\left.\Lambda^{+}=320.14\right)$.

\subsection{Infracommunities}

All fishes studied were parasitized by one or more metazoan species. A total of 4,712 individual parasites were collected: 3,724 in P. numida and 988 in $P$. semifasciata, with mean total abundance of $60.1 \pm 63.4$ and $15 \pm 12.1$, respectively. The different species richness in $P$. numida and $P$. semifasciata were significant: $6.5 \pm 2.5$ (2-16) and $4.8 \pm 2.1$ (1-10), respectively (Table 5, Figure 1).

Parasite abundance in P. numida $(\mathrm{r}=0.547, \mathrm{p}<0.001)$ and $P$. semifasciata $(\mathrm{r}=0.313, \mathrm{p}=0.010)$ were positively correlated with the host's total length. But only in P. numida did parasite species richness correlate positively with the host's total length $(\mathrm{r}=0.449, \mathrm{p}<0.001)$. Also, significant negative relationships of the total body length of $P$. numida with the evenness index ( $r=-0.254$, $\mathrm{p}=0.046$ ), and significant positive ones between the total body length of $P$. semifasciata and the Brillouin index ( $r=0.255, \mathrm{p}=0.045)$ were detected.

No differences between the endoparasite infracommunities of $P$. numida and those of $P$. semifasciata were detected (Table 5). The infracommunities of ectoparasites in $P$. numida had higher values for parasite abundance, parasite richness, the Brillouin index, evenness index, and the Berger-Parker index than the same for the ectoparasites of $P$. semifasciata. A high variability degree was observed in analyzing both the Jaccard and the Sørensen similarity indices (Figure 2 a-d) (see standard deviations), with the same trend being seen in both quantitative and qualitative comparisons.

Comparisons among all three infracommunities (ecto- and endoparasites, and total) showed those of the ectoparasites of $P$. numida as the most heterogeneous group, followed by the infracommunities that included all parasites in the same host. Low similarity values were observed between the three types of the parasite infracommunities of $P$. numida and $P$. semifasciata (Figure 2 a-d).

\section{Discussion}

Parasite communities of the namorado sandperches studied are characterized by the presence of species with low prevalence and abundance, and by high values of parasite species richness in the component communities. These communities are composed basically of endoparasites, mainly digenean and cestodes species. The parasite species richness value found in $P$. numida is the highest recorded for any marine fish from the Neotropical region. An explanation for such a high value could be the feeding habits of these sandperches and their position in the local marine food web; however, information on the subject is relatively scarce. According to Haimovici et al. (1996) and Paiva and Andrade-Tubino (1998), P. numida prefer feeding on fish and crustaceans. Elías and Rajoy (1992) studied the feeding habits of $P$. semifasciata from Argentina and recorded 34 food items in the stomachs of sandperches, mainly fishes (14 spp.) and crustaceans 
Table 1. Prevalence (p), mean intensity (MI), mean abundance (MA) and site of infection (SI) of the metazoan parasites of Pseudopercis numida and Pseudopercis semifasciata from the coastal zone of the State of Rio de Janeiro, Brazil. Standard deviation follows of mean values.

\begin{tabular}{|c|c|c|c|c|c|c|c|}
\hline \multirow[t]{2}{*}{ Parasites } & \multicolumn{3}{|c|}{ Pseudopercis numida } & \multirow[b]{2}{*}{$\mathrm{p}(\%)$} & \multicolumn{3}{|c|}{ Pseudopercis semifasciata } \\
\hline & $\mathbf{p}(\%)$ & MI & MA & & MI & MA & SI \\
\hline \multicolumn{8}{|l|}{ Digenea } \\
\hline $\begin{array}{l}\text { Bucephalus sp. } \\
\text { CHIOC N } 36675\end{array}$ & - & - & - & 7.6 & 1 & $0.1 \pm 0.3$ & Intestine \\
\hline $\begin{array}{l}\text { Choanodera sp. } \\
\text { CHIOC N } 36653\end{array}$ & 4.8 & 1 & $0.05 \pm 0.2$ & 1.5 & 1 & $0.02 \pm 0.1$ & Intestine \\
\hline $\begin{array}{l}\text { Digenea gen. sp. } 1 \text { (juvenile) } \\
\text { CHIOC N } 36677\end{array}$ & - & - & - & 4.6 & 1 & $0.05 \pm 0.2$ & Mesenteries \\
\hline $\begin{array}{l}\text { Digenea gen. sp. } 2 \text { (juvenile) } \\
\text { CHIOC N } 36650\end{array}$ & 1.6 & 1 & $0.02 \pm 0.1$ & - & - & - & Mesenteries \\
\hline $\begin{array}{l}\text { Digenea gen. sp. } 3 \text { (juvenile) } \\
\text { CHIOC N } 36651\end{array}$ & 3.2 & $1.5 \pm 0.7$ & $0.05 \pm 0.3$ & - & - & - & Mesenteries \\
\hline $\begin{array}{l}\text { Digenea gen. sp. } 4 \text { (juvenile) } \\
\text { CHIOC N } 36652\end{array}$ & 1.6 & 1 & $0.02 \pm 0.1$ & 1.5 & 1 & $0.02 \pm 0.1$ & Mesenteries \\
\hline $\begin{array}{l}\text { Digenea gen. sp. } 5 \text { (juvenile) } \\
\text { CHIOC N } 36690\end{array}$ & - & - & - & 1.5 & 1 & $0.02 \pm 0.1$ & Mesenteries \\
\hline $\begin{array}{l}\text { Immature didymozoid } \\
\text { CHIOC No } 36654 / 36681\end{array}$ & 41.9 & $3.0 \pm 3.6$ & $1.3 \pm 2.7$ & 18.2 & $2.1 \pm 1.8$ & $0.4 \pm 1.1$ & Intestine \\
\hline $\begin{array}{l}\text { Hemiurinae gen. sp. } \\
\text { CHIOC N } \mathrm{N}^{\mathrm{o}} 36655 / 36680\end{array}$ & 9.7 & $3.2 \pm 2.2$ & $0.3 \pm 1.1$ & 18.2 & $3.3 \pm 4.9$ & $0.4 \pm 1.1$ & Intestine \\
\hline $\begin{array}{l}\text { Lecithochirium microstomum } \\
\text { CHIOC No } 36656 / 36676\end{array}$ & 16.1 & $2.6 \pm 2.1$ & $0.4 \pm 1.3$ & 21.2 & $1.2 \pm 0.8$ & $0.3 \pm 0.6$ & Stomach \\
\hline $\begin{array}{l}\text { Leurodera decora } \\
\text { CHIOC N } 36657 / 36679\end{array}$ & 17.7 & $2.5 \pm 1.7$ & $0.4 \pm 1.2$ & 34.9 & $1.6 \pm 0.9$ & $0.6 \pm 0.9$ & Intestine \\
\hline $\begin{array}{l}\text { Neolebouria georgenascimentoi } \\
\text { CHIOC No } 36658\end{array}$ & 1.6 & 1 & $0.02 \pm 0.1$ & - & - & - & Intestine \\
\hline $\begin{array}{l}\text { Parahemiurus merus } \\
\text { CHIOC N } 36659 / 36682\end{array}$ & 6.5 & $1.5 \pm 0.6$ & $0.1 \pm 0.4$ & 15.2 & $1.2 \pm 0.4$ & $0.2 \pm 0.5$ & Stomach \\
\hline $\begin{array}{l}\text { Proctoeces sp. } \\
\text { CHIOC N } 36660 / 36686\end{array}$ & 1.6 & 1 & $0.02 \pm 0.1$ & 3 & 1 & $0.03 \pm 0.2$ & Intestine \\
\hline $\begin{array}{l}\text { Prolecitha brasiliensis } \\
\text { CHIOC N } 36661 / 36678\end{array}$ & 4.8 & 1 & $0.05 \pm 0.2$ & 1.5 & 1 & $0.02 \pm 0.1$ & Intestine \\
\hline $\begin{array}{l}\text { Opecoeloides sp. } \\
\text { CHIOC No } 36662 / 36687\end{array}$ & 1.6 & 1 & $0.02 \pm 0.1$ & 3 & 1 & $0.03 \pm 0.2$ & Intestine \\
\hline $\begin{array}{l}\text { Stephanostomum sp. } \\
\text { CHIOC No } 36663\end{array}$ & 3.2 & 1 & $0.03 \pm 0.2$ & - & - & - & Intestine \\
\hline \multicolumn{8}{|l|}{ Monogenea } \\
\hline $\begin{array}{l}\text { Anoplodiscus longivaginatus } \\
\text { CHIOC N }{ }^{\circ} 36664\end{array}$ & 3.2 & 1 & $0.03 \pm 0.2$ & - & - & - & Gills \\
\hline $\begin{array}{l}\text { Neobenedenia sp. } \\
\text { CHIOC N } \mathrm{N}^{\circ} 36666 / 36683\end{array}$ & 1.6 & 1 & $0.02 \pm 0.1$ & 3 & 1 & $0.03 \pm 0.2$ & Gills \\
\hline $\begin{array}{l}\text { Encotyllabe sp. } \\
\text { CHIOC N } 36665\end{array}$ & 1.6 & 1 & $0.02 \pm 0.1$ & 1.5 & 1 & $0.02 \pm 0.1$ & Gills \\
\hline $\begin{array}{l}\text { Microcotyle pseudopercis } \\
\text { CHIOC N } 36667 / 36688\end{array}$ & 62.9 & $7.2 \pm 8.9$ & $4.5 \pm 7.9$ & 59.1 & $2.5 \pm .2 .1$ & $1.5 \pm 2.1$ & Gills \\
\hline $\begin{array}{l}\text { Pseudempleurosoma gibsoni } \\
\text { CHIOC N } \mathrm{N}^{\circ} 36668 / 36685\end{array}$ & 4.8 & 1 & $0.05 \pm 0.2$ & 21.2 & $1.6 \pm .0 .9$ & $0.3 \pm 0.8$ & Stomach \\
\hline \multicolumn{8}{|l|}{ Cestoda } \\
\hline $\begin{array}{l}\text { Callitetrarhynchus gracilis } \\
\text { (plerocercoid) CHIOC No } 36669\end{array}$ & 1.6 & 1 & $0.02 \pm 0.1$ & - & - & - & Mesenteries \\
\hline
\end{tabular}


Table 1. Continued...

\begin{tabular}{|c|c|c|c|c|c|c|c|}
\hline \multirow[t]{2}{*}{ Parasites } & \multicolumn{3}{|c|}{ Pseudopercis numida } & \multicolumn{4}{|c|}{ Pseudopercis semifasciata } \\
\hline & p (\%) & MI & MA & $\mathbf{p}(\%)$ & MI & MA & SI \\
\hline $\begin{array}{l}\text { Nybelinia sp. (plerocercoid) } \\
\text { CHIOC } 36673\end{array}$ & 3.2 & 1 & $0.03 \pm 0.2$ & - & - & - & Mesenteries \\
\hline $\begin{array}{l}\text { Progrillotia dollfusi } \\
\text { (plerocercoid) CHIOC No } 36684\end{array}$ & 71 & $2.8 \pm 2$ & $2 \pm 2.2$ & 65.2 & $4.7 \pm 6.5$ & $3.1 \pm 5.7$ & Mesenteries \\
\hline $\begin{array}{l}\text { Scolex pleuronectis } \\
\text { CHIOC No } 36670 / 36689\end{array}$ & 43.6 & $16.2 \pm 38.2$ & $7 \pm 26.2$ & 53 & $5.8 \pm 6.8$ & $3.1 \pm 5.7$ & Intestine \\
\hline \multicolumn{8}{|l|}{ Acanthocephala } \\
\hline $\begin{array}{l}\text { Gorgorhynchus sp. } \\
\text { CHIOC No } 36671\end{array}$ & 30.7 & $5 \pm 3.7$ & $1.5 \pm 3.1$ & - & - & - & Intestine \\
\hline $\begin{array}{l}\text { Heterosentis } s p . \\
\text { CHIOC } \mathrm{N}^{\circ} 36672\end{array}$ & 22.6 & $4.1 \pm 4.2$ & $0.9 \pm 2.6$ & - & - & - & Intestine \\
\hline \multicolumn{8}{|l|}{ Nematoda } \\
\hline Anisakis sp. (larval) & 4.8 & $1.7 \pm 0.6$ & $0.1 \pm 0.4$ & - & - & - & Mesenteries \\
\hline $\begin{array}{l}\text { Paracapillaria argentinensis } \\
\text { CHIOC } \mathrm{N}^{\circ} 35454 / 35460\end{array}$ & 17.7 & $3.6 \pm 2.3$ & $0.7 \pm 1.7$ & 7.6 & $6.4 \pm 5.2$ & $0.5 \pm 2.1$ & Intestine \\
\hline $\begin{array}{l}\text { Cucullanus carioca } \\
\text { CHIOC No } 35452\end{array}$ & 32.3 & $4.1 \pm 4.3$ & $1.3 \pm 3.1$ & 54.6 & $2.9 \pm 4$ & $1.6 \pm 3.3$ & Intestine \\
\hline Dichelyne sp. & 8.1 & $1.6 \pm 1.3$ & $0.1 \pm 0.6$ & 10.6 & $1.6 \pm 1$ & $0.2 \pm 0.6$ & Intestine \\
\hline $\begin{array}{l}\text { Hysterothylacium sp. (larval) } \\
\text { CHIOC } \mathrm{N}^{\circ} 35453\end{array}$ & 43.6 & $2 \pm 1.6$ & $0.9 \pm 1.4$ & 22.7 & $2.5 \pm 1.3$ & $0.6 \pm 1.2$ & Mesenteries \\
\hline $\begin{array}{l}\text { Procamallanus sp. } \\
\text { CHIOC No } 35461\end{array}$ & 1.6 & 1 & $0.02 \pm 0.1$ & 4.6 & $1.7 \pm 0.6$ & $0.1 \pm 0.4$ & Intestine \\
\hline $\begin{array}{l}\text { Raphidascaris sp. (larval) } \\
\text { CHIOC N } 35451\end{array}$ & 25.8 & $3.8 \pm 5.4$ & $1 \pm 3.2$ & 24.2 & $4.5 \pm 8.8$ & $1.1 \pm 4.7$ & Mesenteries \\
\hline Terranova sp. (larval) & 4.8 & $1.3 \pm 0.6$ & $0.1 \pm 0.3$ & 1.5 & 1 & $0.02 \pm 0.1$ & Mesenteries \\
\hline \multicolumn{8}{|l|}{ Hirudinea } \\
\hline $\begin{array}{l}\text { Piscicolidae gen. sp. } \\
\text { CHIOC N } 35459\end{array}$ & 6.5 & 1 & $0.1 \pm 0.3$ & 3 & 1 & $0.03 \pm 0.2$ & Gills \\
\hline \multicolumn{8}{|l|}{ Isopoda } \\
\hline $\begin{array}{l}\text { Cymothoidae gen. sp. } \\
\text { CHIOC No } 35457\end{array}$ & 37.1 & $2 \pm 1.3$ & $0.8 \pm 1.3$ & - & - & - & Nasal cavity \\
\hline $\begin{array}{l}\text { Gnathia sp. (larval) } \\
\text { CHIOC No } 35458 \\
\end{array}$ & 100 & $36.2 \pm 51.5$ & $36.2 \pm 51.5$ & 13.6 & $5.1 \pm 5.1$ & $0.7 \pm 2.5$ & Gills \\
\hline
\end{tabular}

(7 spp.), which are potential intermediate hosts of endoparasite species whose life cycles consist of long-lived larval stages within intermediate and paratenic hosts (Marcogliese, 2001, 2002, 2004). The presence of some larval helminths suggested the possibility of sandperches also occupying an intermediate level in the marine food web, mainly in the early stages when crustaceans are their preferred food item (Elias and Rajoy, 1992). Luque et al. (2004) listed parasite richness values ranging from 3 to 28 for 50 fish species from Rio de Janeiro. Eight of these hosts showed richness values equal to or higher than 20. Some demersal and benthic fishes had the highest richness values of this region, e.g., Micropogonias furnieri (28), Dactylopterus volitans (27), and Mugil platanus (25) (Knoff et al., 1997; Alves and Luque, 2001; Cordeiro and Luque, 2005).

With respect to the high abundance values recorded for some ectoparasite species, these might be related to the population density increase of namorado sandperches in offshore reproductive grounds (Venerus et al., 2005), which might facilitate transmission of ectoparasites with a direct life-cycle. The dominant ectoparasite species Gnathia sp. is a temporary fish parasite whose life-cycle and ecology are little known. However, adults of the species are generally abundant in the intertidal zones (Smit et al., 2003).

Aggregated distribution of the parasite populations is considered one of the most common features of metazoan parasite infections (Poulin, 1993). In the present study, two aggregation measures were used: the variance-to-mean ratio and a discrepancy index. The latter is a measure of the disparity between the observed and uniform distributions of the parasite population in host samplings, with values ranging from 0 to 1 (Poulin, 1993). Values obtained from these two indices revealed a high aggregation level, confirming a characteristic typical of 
Table 2. Values of variance to mean ratio of parasite abundance (ID) and index of Discrepancy (D) of the metazoan parasites of Pseudopercis numida and P. semifasciata from the coastal zone of the State of Rio de Janeiro, Brazil.

\begin{tabular}{lcccc}
\hline \multirow{2}{*}{ Parasites } & \multicolumn{2}{c}{ Pseudopercis numida } & \multicolumn{2}{c}{ Pseudopercis semifasciata } \\
\cline { 2 - 5 } & ID & D & ID & D \\
\hline Immature didymozoid & 5.845 & 0.780 & 3.230 & 0.876 \\
Hemiurinae gen. sp. & 3.883 & 0.914 & 9.335 & 0.903 \\
Lecithochirium microstomum & 3.796 & 0.889 & 1.471 & 0.810 \\
Leurodera decora & 3.209 & 0.872 & 1.544 & 0.731 \\
Parahemiurus merus & - & - & 1.169 & 0.856 \\
Microcotyle pseudopercis & 13.714 & 0.707 & 2.852 & 0.643 \\
Pseudempleurosoma gibsoni & - & - & 1.785 & 0.832 \\
Progrillotia dollfusi & 2.532 & 0.553 & 10.427 & 0.678 \\
Scolex pleuronectis & 97.232 & 0.882 & 10.569 & 0.744 \\
Gorgorhynchus sp. & 6.221 & 0.792 & - & - \\
Heterosentis sp. & 7.357 & 0.866 & - & - \\
Paracapillaria argentinensis & 4.426 & 0.859 & - & - \\
Cucullanus carioca & 7.233 & 0.812 & 8.571 & 0.739 \\
Dichelyne sp. & - & - & 1.954 & 0.908 \\
Hysterothylacium sp. & 2.390 & 0.713 & 2.532 & 0.822 \\
Raphidascaris sp. & 10.247 & 0.871 & 19.905 & 0.893 \\
Cymothoidae gen. sp. & 2.149 & 0.737 & - & - \\
Gnathia sp. & 73.295 & 0.615 & 9.049 & 0.917 \\
\hline
\end{tabular}

Table 3. Values of Pearson's correlation coefficient (r) to evaluate possible relationships among the host total length and prevalence and abundance of the metazoan parasites of Pseudopercis numida and P. semifasciata from the coastal zone of the State of Rio de Janeiro, Brazil.

\begin{tabular}{lcccc}
\hline \multirow{2}{*}{ Parasites } & \multicolumn{2}{c}{ Pseudopercis numida } & \multicolumn{2}{c}{ Pseudopercis semifasciata } \\
\cline { 2 - 5 } & Prevalence & Abundance & Prevalence & Abundance \\
\hline Immature didymozoid & 0.877 & $0.291^{*}$ & 0.942 & 0.220 \\
Hemiurinae gen. sp. & - & - & -0.413 & 0.066 \\
Lecithochirium microstomum & -0.885 & -0.132 & 0.452 & 0.207 \\
Leurodera decora & $0.961^{*}$ & $0.343^{*}$ & -0.938 & -0.229 \\
Parahemiurus merus & - & - & 0.593 & -0.144 \\
Microcotyle pseudopercis & $0.948^{*}$ & $0.473^{*}$ & 0.792 & $0.346^{*}$ \\
Pseudempleurosoma gibsoni & - & - & -0.909 & -0.24 \\
Progrillotia dollfusi & -0.74 & -0.211 & 0.375 & $0.257^{*}$ \\
Scolex pleuronectis & $0.979^{*}$ & 0.235 & 0.112 & $-0.244^{*}$ \\
Gorgorhynchus sp. & 0.661 & -0.042 & - & - \\
Heterosentis sp. & 0.744 & 0.032 & - & - \\
Paracapillaria argentinensis & 0.886 & 0.238 & - & - \\
Cucullanus carioca & 0.909 & $0.326^{*}$ & 0.875 & $0.351^{*}$ \\
Dichelyne sp. & - & - & 0.471 & 0.219 \\
Hysterothylacium sp. & 0.605 & -0.007 & 0.246 & $0.269^{*}$ \\
Raphidascaris sp. & 0.716 & 0.241 & 0.287 & $0.263^{*}$ \\
Cymothoidae gen. sp. & -0.621 & 0.229 & - & - \\
Gnathia sp. & - & $0.419^{*}$ & 0.569 & $0.352^{*}$ \\
\hline
\end{tabular}

*significant values.

metazoan parasite populations. Apparently, neither of the two host species has been affected by the aggregation level of the species composing the parasite communities, because no significant differences were detected in the variance/mean ratio and discrepancy index between the parasite species common to both. This finding raises the possibility of patterns similar to those of the two sympatric and congeneric species hosting local parasite fauna. 
Table 4. Values of Chi-square $\chi^{2}$ and Student $t$ tests for comparisons of prevalence and abundance of component parasite species of Pseudopercis numida (Pn) and P. semifasciata (Ps) from the coastal zone of the State of Rio de Janeiro, Brazil.

\begin{tabular}{llccc}
\hline \multicolumn{1}{c}{ Parasites } & $\chi^{2}$ & & $\boldsymbol{t}$ & \\
\hline Immature didymozoid & $8.64^{*}$ & $\mathrm{Pn}>\mathrm{Ps}$ & $2.84^{*}$ & $\mathrm{Pn}>\mathrm{Ps}$ \\
Hemiurinae gen. sp. & 1.91 & - & -1.02 & - \\
Lecithochirium microstomum & 0.54 & - & 0.18 & - \\
Leurodera decora & $4.80^{*}$ & $\mathrm{Pn}<\mathrm{Ps}$ & -1.58 & - \\
Microcotyle pseudopercis & 0.20 & - & $2.5^{*}$ & $\mathrm{Pn}>\mathrm{Ps}$ \\
Progrillotia dollfusi & 0.50 & - & $-34.0^{*}$ & $\mathrm{Pn}<\mathrm{Ps}$ \\
Scolex pleuronectis & 1.15 & - & 0.57 & - \\
Cucullanus carioca & $5.63^{*}$ & $\mathrm{Pn}<\mathrm{Ps}$ & -1.26 & - \\
Hysterothylacium sp. & 6.29 & - & 1.48 & - \\
Raphidascaris sp. & 0.04 & - & -0.25 & - \\
Gnathia sp. & $93.1^{*}$ & $\mathrm{Pn}>\mathrm{Ps}$ & $15.3^{*}$ & $\mathrm{Pn}>\mathrm{Ps}$ \\
\hline
\end{tabular}

*significant values.

Table 5. Characteristics of the metazoan parasites infracommunities found in Pseudopercis numida and P. semifasciata from the costal zone of the State of Rio de Janeiro, Brazil. $t$ = values of the Student test to comparison between the two hosts.

\begin{tabular}{|c|c|c|c|}
\hline Characteristics & $\begin{array}{c}\text { Pseudopercis numida } \\
(\mathrm{n}=62)\end{array}$ & $\begin{array}{l}P \text { semifasciata } \\
(\mathrm{n}=66)\end{array}$ & $t$ \\
\hline \multicolumn{4}{|l|}{ All species } \\
\hline Parasite species richness & 36 & 28 & - \\
\hline Total number of specimens & 3724 & 988 & - \\
\hline Mean species richness & $6.45 \pm 2.45(2-16)$ & $4.76 \pm 2.07(1-10)$ & $-4.18 *$ \\
\hline Mean total abundance & $60.07 \pm 63.45(4-274)$ & $14.97 \pm 12.05(1-57)$ & $-7.83^{*}$ \\
\hline Mean Brillouin index & $0.43 \pm 0.17(0.1-0.82)$ & $0.38 \pm 0.18(0-0.69)$ & -1.69 \\
\hline Mean evenness index & $0.62 \pm 0.19(0.56-0.88)$ & $0.69 \pm 0.25(0-0.95)$ & 1.34 \\
\hline Dominant species & Gnathia sp. & Scolex pleuronectis & - \\
\hline Mean Berger-Parker's index & $0.58 \pm 0.2(0.21-0.95)$ & $0.52 \pm 0.22(0.2-1)$ & -1.57 \\
\hline \multicolumn{4}{|l|}{ Endoparasite species } \\
\hline Parasite species richness & 29 & 23 & - \\
\hline Total number of individuals & 1144 & 820 & - \\
\hline Mean species richness & $4.34 \pm 2.41(0-14)$ & $3.79 \pm 1.8(0-8)$ & 1.033 \\
\hline Mean total abundance & $18.45 \pm 27(0-170)$ & $12.42 \pm 11.15(0-54)$ & 1.356 \\
\hline Mean Brillouin index & $0.35 \pm 0.2(0-0.83)$ & $0.31 \pm 0.17(0-0.64)$ & 1.127 \\
\hline Mean evenness index & $0.6 \pm 0.31(0-0.96)$ & $0.62 \pm 0.31(0-0.95)$ & 1.056 \\
\hline Dominant species & Scolex pleuronectis & Scolex pleuronectis & - \\
\hline Mean Berger-Parker's index & $0.53 \pm 0.23(0.21-1)$ & $0.54 \pm 0.23(0.18-1)$ & -0.222 \\
\hline \multicolumn{4}{|l|}{ Ectoparasite species } \\
\hline Parasite species richness & 7 & 5 & - \\
\hline Total number of individuals & 2580 & 168 & - \\
\hline Mean species richness & $2.11 \pm 0.83(1-5)$ & $0.99 \pm 0.85(0-4)$ & $8.049 *$ \\
\hline Mean total abundance & $41.6 \pm 56.9(1-267)$ & $2.6 \pm 3.2(0-15)$ & $12.040 *$ \\
\hline Mean Brillouin index & $0.11 \pm 0.09(0-0.36)$ & $0.03 \pm 0.08(0-0.38)$ & $4.871 *$ \\
\hline Mean evenness index & $0.32 \pm 0.32(0-0.98)$ & $0.13 \pm 0.29(0-0.89)$ & $4.159 *$ \\
\hline Dominant species & Gnathia sp. & Microcotyle pseudopercis & - \\
\hline Mean Berger-Parker's index & $0.84 \pm 0.15(0.5-1.0)$ & $0.67 \pm 0.44(0.33-1)$ & $3.368 *$ \\
\hline
\end{tabular}

*significant values. 
Pseudopercis numida and P. semifasciata are distributed along the coastal zone of State of Rio de Janeiro. Sympatric species are expected to show some degree of similarity in their community composition (in the case of ectoparasites) because of possible contact of the host populations, as well as similarity in food spectra (in the

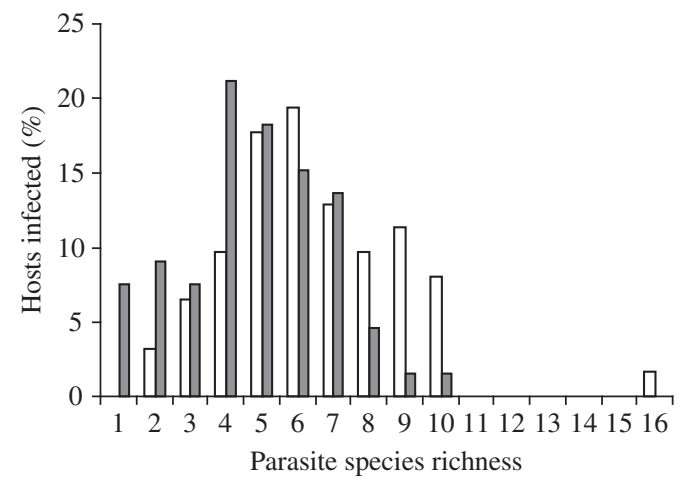

Figure 1. Distribution of species richness in the parasite infracommunities of Pseudopercis numida and P. semifasciata from the coastal zone of the State of Rio de Janeiro, Brazil. case of endoparasites). Mean values of the similarity indices between $P$. numida and $P$. semifasciata were lower than 0.2 , showing the same pattern for qualitative and quantitative similarity, with no significant differences between groups consisting of both ecto- and endoparasites. Similarity was even higher at the component community level. The same was previously observed for various taxonomically related or congeneric species of marine fishes from Rio de Janeiro (Luque et al., 1996; Takemoto et al., 1996; Luque and Alves, 2001; Alves et al., 2004; 2005) and might support similar use by the local pool of parasite species, facilitated in the case of the sandperches by their sedentary habits and restricted geographic distribution. Since $P$. numida and $P$. semifasciata have overlapping geographical distribution, this could contribute to increased dispersion of some specialist parasites, as has been observed for the monogenean Microcotyle pseudopercis, in a way similar to those mentioned by Suriano and Labriola (1999) and Alves et al. (2004) for the specialist monogenean Diclidophoroides maccallumi, which is parasitic in two congeneric species of the Brazilian codling (Urophycis spp.).

In the present study, host size was not always correlationed with the prevalence and abundance of the parasite species, while at the infracommunity level the total number of parasite individuals, in addition to their
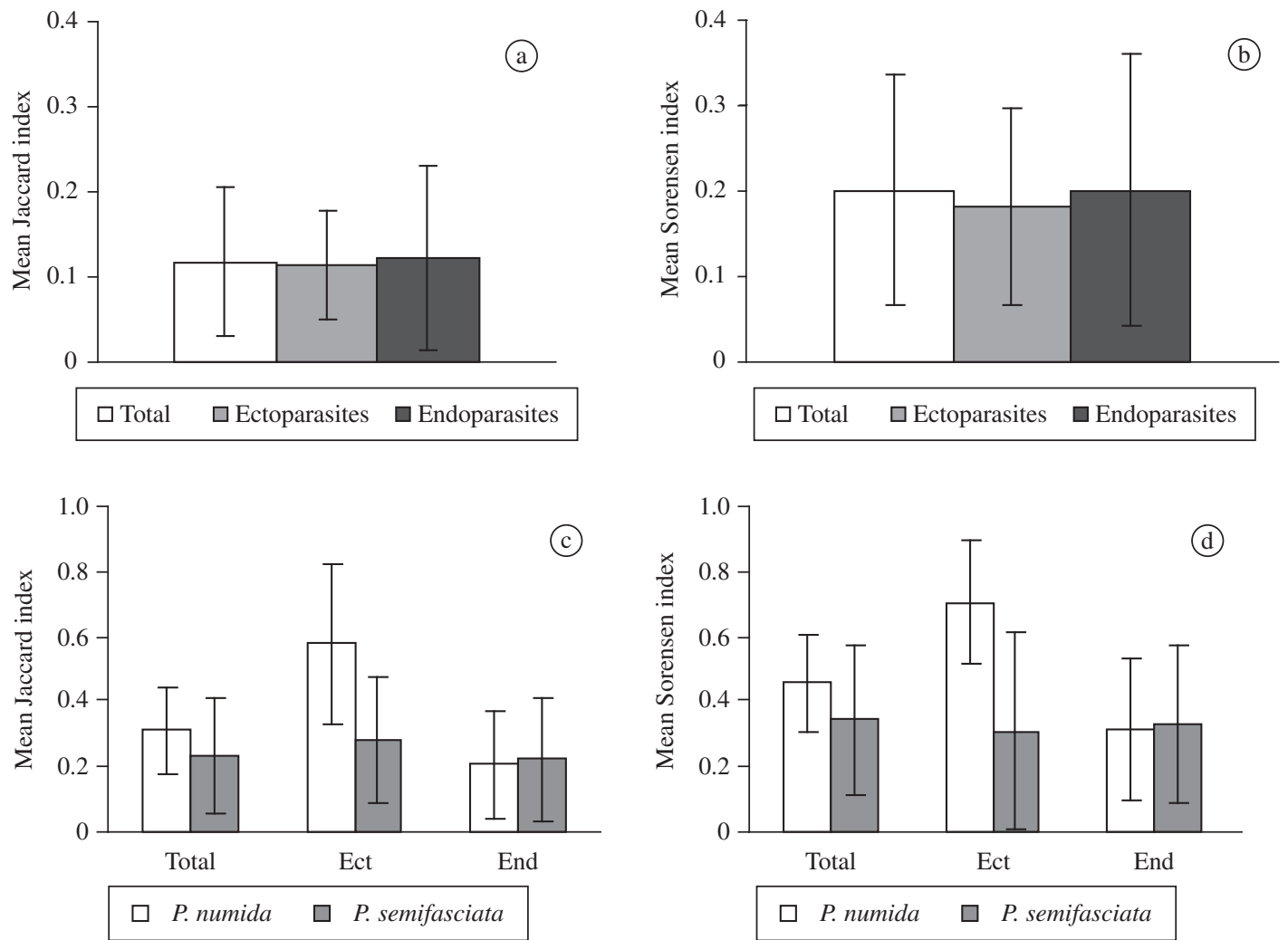

Figure 2. Similarity indexes of parasite infracommunities of Pseudopercis numida and P. semifasciata from the coastal zone of the State of Rio de Janeiro, Brazil. a) qualitative similarity between $P$. numida and $P$. semifasciata, b) quantitative similarity between $P$. numida and $P$. semifasciata, c) qualitative similarity within each fish host; and d) quantitative similarity within each fish host. 
diversity and richness, generally presented positive relationships with host size. As pointed out by Poulin (2000), these patterns cannot be generalized because in many host-parasite species systems the correlations are positive but weak and nonsignificant. Also, ontogenetical changes in feeding behavior might influence parasite prevalence and abundance in the different host size classes (Saad-Fares and Combes, 1992). In contrast, at the component community level, size proved to be the main predictor of total parasite species richness in marine fish from the Brazilian littoral, since its host is the best measure of total nutrient or energy amounts available for parasite exploitation (Luque et al., 2004).

Significant differences were detected between total abundance and parasite species richness in $P$. numida and $P$. semifasciata, with higher values being detected for $P$. numida. These values (shown in Table 5) were notably influenced by differences between the descriptor values of ectoparasite infracommunities, which also demonstrated higher homogeneity in their composition. However, these results could be influenced by the host size differences ( $P$. numida showed a mean host size higher than that of $P$. semifasciata). Moreover, possible differences, which might originate in the dynamic of the host populations, local presence of ectoparasite free-living larval stages, specificity, and immunological aspects should be not discarded. These factors could also explain differences in parasite species populations infecting the two host species: of the six parasite species showing prevalence and/or abundance differences in $P$. numida and $P$. semifasciata, three showed higher values in the first, and three in the second.

In order to compare parasite communities of namorado sandperches with those of other recently studied marine fish species from Rio de Janeiro, average taxonomic distinctness and variance of taxonomic distinctness were calculated (see Luque et al. 2004). Values indicated by the average taxonomic indices and their variances were not very different between the two species of sandperches, and they were lower than those of the majority of the 50 fish species studied by Luque et al. (2004). As remarked by Luque et al. (2004), previous studies have focused almost exclusively on parasite species richness as a measure of parasite diversity. However, species richness is not necessarily a measure of all biodiversity facets, which is demonstrated by the fact that many fish species with high species richness values do not show higher values of taxonomic distinctness. This situation is reinforced by the parasite communities of $P$. numida and $P$. semifasciata, species with high values of parasite richness, but whose taxonomic composition shows few differences.

Acknowledgements - José L. Luque was supported by a Research Fellowship from CNPq (Conselho Nacional de Pesquisa e Desenvolvimento Tecnológico, Brazil) during this study. Nilza N. Felizardo and Luiz E. R. Tavares were supported by the Graduate Student Fellowships from CAPES (Coordenação de Aperfeiçoamento do Pessoal de Ensino Superior, Brazil).

\section{References}

ALVES, DR., PARAGUASSÚ, AR. and LUQUE, JL., 2004. Metazoários parasitos da abrótea, Urophycis brasiliensis (Kaup, 1858), (Osteichthyes: Phycidae) do litoral do estado do Rio de Janeiro, Brasil. Rev. Brasil. Parasitol. Vet., vol. 13, no. 2, p. $49-55$.

ALVES, DR. and LUQUE, JL., 2001. Community ecology of the metazoan parasites of the white croaker Micropogonias furnieri (Osteichthyes: Sciaenidae) from the coastal zone of the State of Rio de Janeiro, Brazil. Mem. Inst. Oswaldo Cruz, vol. 96 , no. 2, p. 145-153.

ALVES, DR., PARAGUASSÚ, AR. and LUQUE, JL., 2005. Community ecology of the metazoan parasites of the grey triggerfish, Balistes capriscus Gmelin, 1789 and queen triggerfish B. vetula Linnaeus, 1758 (Osteichthyes: Balistidae) from the state of Rio de Janeiro, Brazil. Rev. Brasil. Parasitol. Vet., vol. 14, no. 2, p. 71-77.

AMATO, JFR. and CEZAR, AD., 1994. A new species of Microcotyle Van Beneden and Hesse, 1863, parasitic on "namorado", Pseudopercis numida Ribeiro, 1903 and P. semifasciata (Cuvier, 1829), from the coast of the state of Rio de Janeiro, Brazil. Rev. Brasil. Parasitol. Vet., vol. 3, no. 1, p. 41-44.

BUSH, AO., AHO, JM. and KENNEDY, CR., 1990. Ecological versus phylogenetic determinants of helminth parasite community richness. Evol. Ecol., vol. 4, no. 1, p. 1-20.

BUSH, AO., LAFFERTY, KD., LOTZ, JM. and SHOSTAK, AW., 1997. Parasitology meets ecology on its own terms: Margolis et al. revisited. J. Parasitol., vol. 83, no. 4, p. 575-583.

CORDEIRO, AS. and LUQUE, JL., 2005. Metazoários parasitos do coió Dactylopterus volitans (Linnaeus, 1758) (Osteichthyes: Dactylopteridae) do litoral do Estado do Rio de Janeiro, Brasil. Acta Scientiarum, vol. 27, no. 2, p. 129-123.

ELÍAS, I. and RAJOY, CR., 1992. Hábitos alimentarios del "salmon del mar" Pseudopercis semifasciata (Cuvier, 1829): Pinguipedidae en aguas norpatagónicas argentinas. Rev. Biol. Mar. Valparaíso, vol. 27, no. 1, p. 133-146.

FROESE, R. and PAULY, D., 2007. FishBase. World Wide Web electronic publication. version (06/2007). Available from: www. fishbase.org.

GONZALEZ, RA. and TANZOLA, RD., 2000. On the presence of Sarcotaces verrucosus (Copepoda) in the Southwest Atlantic. Acta Parasitol., vol. 45, no. 4, p. 345-349.

HAIMOVICI, M., MARTINS, AS. and VIEIRA, PC., 1996. Distribuição e abundância de peixes teleósteos demersais sobre a plataforma continental do Sul do Brasil. Rev. Brasil. Biol., vol. 56 , no. 1 , p. $27-50$.

KNOFF, M., LUQUE, JL. and AMATO, JFR., 1997. Community ecology of the metazoan parasites of grey mullets, Mugil platanus (Osteichthyes: Mugilidae) from the littoral of the State of Rio de Janeiro, Brazil. Rev. Brasil. Biol. vol. 57, no. 3, p. 441-454.

LUQUE, JL., 2004. Parasitologia de peixes marinhos na América do Sul: Estado atual e perspectivas. In RANZANIPAIVA, MJ., TAKEMOTO, RM., LIZAMA, MAP. (eds.). Sanidade de organismos aquáticos. São Paulo: Editora Varela. p. 199-216. 
LUQUE, JL. and ALVES, DR., 2001. Ecologia das comunidades parasitárias do xaréu, Caranx hippos e do xerelete, Caranx latus (Osteichthyes: Carangidae) do litoral do Estado do Rio de Janeiro, Brasil. Rev. Brasil. Zool., vol. 18, no. 2, p. 399-410.

LUQUE, JL. and POULIN, R., 2004. Use of fish as intermediate hosts by helminth parasites. Acta Parasitol., vol. 49, no. 4, p. 353-361.

LUQUE, JL., AMATO, JFR. and TAKEMOTO, RM., 1996. Comparative analysis of the communities of metazoan parasites of Orthopristis ruber and Haemulon steindachneri (Osteichthyes: Haemulidae) from the southeastern Brazilian littoral: I. Structure and influence of the size and sex of hosts. Rev. Brasil. Biol., vol. 56, no. 2, p. 279-292.

LUQUE, JL., MOUILLOT, D. and POULIN, R., 2004. Parasite biodiversity and its determinants in coastal marine teleost fishes of Brazil. Parasitology, vol. 128, no. 6, p. 671-682.

MAGURRAN, AE., 1988. Ecological diversity and its measurement. New Jersey: Princeton University Press. 192 p.

MARCOGLIESE, DJ., 2001. Pursuing parasites up the food chain: implications of food web structure and function on parasite communities in aquatic systems. Acta Parasitol., vol. 46 , no. 2 , p. $82-93$.

-, 2002. Food webs and the transmission of parasites to marine fish. Parasitology, vol. 124, no. 7, p. 83-99.

-, 2004. Parasites: Small players with crucial roles in the ecological theater. Ecohealth, vol. 1, no. 2, p. 151-164.

MENEZES, NA. and FIGUEIREDO, JL., 1985. Manual de peixes marinhos do sudeste do Brasil. V. Teleostei (4). São Paulo: Museu de Zoologia, Universidade de São Paulo. 105 p.

PAIVA, MP. and ANDRADE-TUBINO, MF., 1998. Distribuição e abundância de peixes bentônicos explotados pelos linheiros ao largo do Sudeste do Brasil (1986-1995). Rev. Brasil. Biol., vol. 58, no. 4, p. 619-632.

POULIN, R., 1993. The disparity between observed and uniform distributions: a new look at parasite aggregation. Int. J. Parasitol., vol. 23, no. 7, p. 937-944.
-, 2000. Variation in the intraspecific relationship between fish length and intensity of parasitic infection: biological and statistical causes. J. Fish. Biol., vol. 56, no. 1, p. 123-137.

RÓSZA, L., REICZIGEL, J. and MAJOROS, G., 2000. Quantifying parasites in samples of hosts. J. Parasitol., vol. 86, no. 2, p. 228-232.

SAAD-FARES, A. and COMBES, C., 1992. Abundance/host size relationships in a fish trematode community. J. Helminthol., vol. 66, no. 3, p. 187-192.

SANTOS, CP. and CARBONEL, CAA., 2000. The role of physical factors in the distribution of the monogenean fauna in the midwestern and southwestern Atlantic. In SALGADO-MALDONADO, G., GARCIA-ALDRETE, AN., VIDAL-MARTINEZ, VM. (eds.) Metazoan Parasites in the Neotropics: A Systematic and Ecological Perspective. México: Instituto de Biologia, UNAM. p. 61-75.

SMIT, NJ., BASSON, L. and VANAS, JG., 2003. Life cycle of the temporary fish parasite, Gnathia africana (Crustacea: Isopoda: Gnathiidae). Fol. Parasitol., vol. 50, no. 2, p. 135-142.

SURIANO, DM. and LABRIOLA, JB., 1999. Diclidophoroides maccallumi Price, 1943 and Neoheterobothrium paralichthys sp. n. (Monogenea: Diclidophoridae) parasites of fishes (Gadiformes and Pleuronectiformes) from the Southwestern Atlantic Ocean. Acta Parasitol. vol. 44, no. 3, p. 160-164.

TAKEMOTO, RM., AMATO, JFR. and LUQUE, JL., 1996. Comparative analysis of the metazoan parasite communities of leatherjackets, Oligoplites palometa, O. saurus and $O$. saliens (Osteichthyes: Carangidae) from Sepetiba Bay, Rio de Janeiro, Brazil. Rev. Brasil. Biol. vol. 56, no. 4, p. 639-650.

VENERUS, LA., MACHINANDIARENA, L., EHRLICH, MD. and PARMA, AM., 2005. Early life history of the Argentine sandperch Pseudopercis semifasciata (Pinguipedidae) off northern Patagonia. Fish. Bull., vol. 103, no. 1, p. 195-206.

ZAR, JH., 1996. Biostatistical Analysis. Upper Saddle River, New Jersey: Prentice-Hall Inc. 918 p. 